\title{
SHIP MOORING TO JETTIES UNDER THE CROSSCURRENT
}

\author{
Vytautas Paulauskas, Donatas Paulauskas, Birutė Plačienė, Raimondas Barzdžiukas \\ Dept of Marine Engineering, Klaipeda University, Lithuania
}

Submitted 3 November 2015; resubmitted 9 May 2016; accepted 24 August 2016; published online 04 September 2017

\begin{abstract}
Quay walls or jetties in some ports or certain places of the ports are located in such a way that currents act at a particular angle to quay walls or jetties. Additional forces created by currents on mooring or moored ships as well as other forces produced by the wind, waves or shallow water effect should be taken in account when designing quay walls or jetties for ship mooring operations. The article describes ship mooring under crosscurrent conditions, calculates mooring methodology, experimentally examines the received theoretical results and provides recommendations to designers and ship operators when quay walls or jetties are arranged at a particular angle to the current.
\end{abstract}

Keywords: ship mooring; quay walls; jetties; mooring conditions; ports.

\section{Introduction}

Some ports have built quay walls and jetties (Figs 1-3) located at a particular angle to the direction of currents (PIANC 1995). Large ships having long length and deep draft face a significant influence of currents. The process of designing and exploiting quay walls shows that currents via moored ships create great additional forces on quay walls and fenders (PIANC 1984; 2002; Lee, C.-K., Lee, S.-G. 2008).

The influence of currents on mooring or moored ships, in case of wide angles between quay walls or jetties and the direction of currents, very often requests additional support of forces such as tugs (Gucma, Montewka 2005; Paulauskas, V., Paulauskas, D. 2011). The forces created by currents and other external factors can reach a very big influence on a ship, and therefore sometimes it is necessary to wait for a decrease in current velocity to execute ship mooring operations (Skjetne 2003; Zalewski, Montewka 2007).

Similar tidal crosscurrents and the locations of quay walls or jetties can be found in a number of ports situated in rivers or close to the Seashore where high tilde effects may exist. As for the above mentioned and other similar ports or terminals, big ships are moored only through 'tilde window', which means a period of time from about one hour before high water until approximately one hour after it when the tilde current changes direction and has minimal velocity.

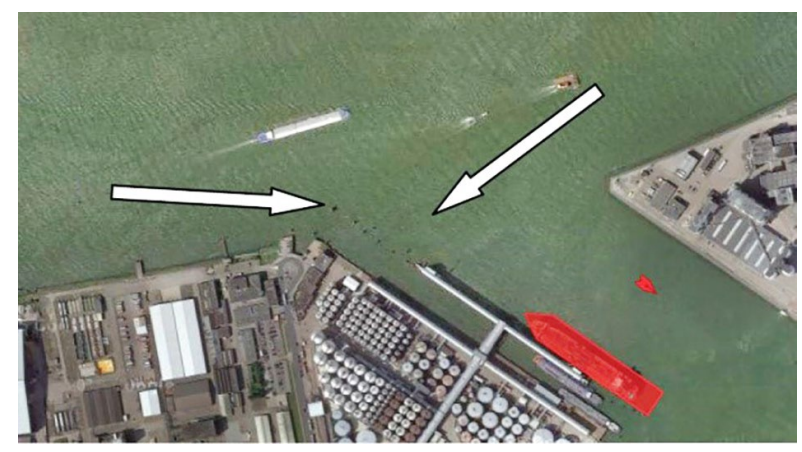

Fig. 1. Jetties for the oil terminal at the Port of Hamburg and directions of tidal currents

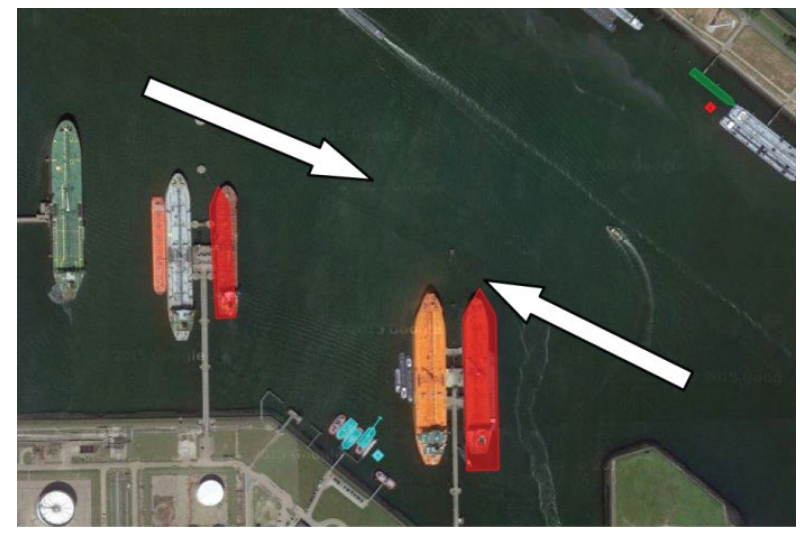

Fig. 2. Jetties for the oil terminal at the Port of Rotterdam and directions of tidal currents 


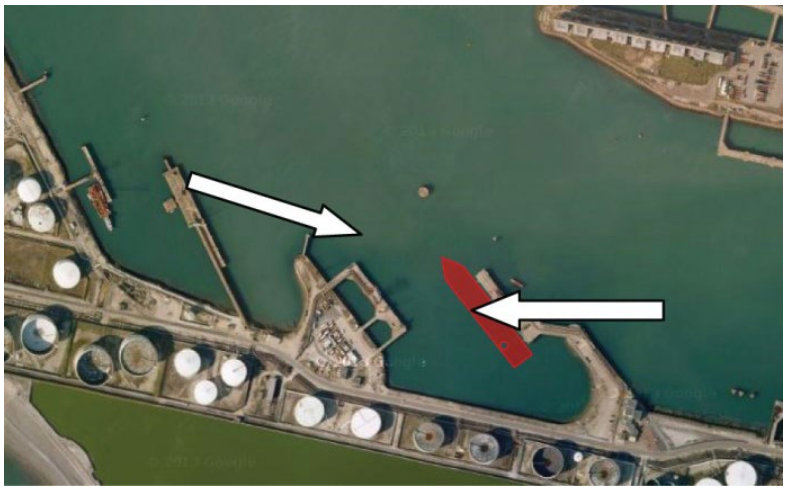

Fig. 3. Jetties for the oil terminal at the Port of Le-Havre and directions of tidal currents

As regards the ports located on rivers where the current acts one direction and current velocity is relatively high in some seasons (after heavy rain periods in spring and autumn), it is sometimes necessary to wait for a few days to make safe mooring operations.

An effective and useful methodology for evaluating the influence of the current and other external factors acting on the mooring or moored ship is very important for making rational decisions on the optimization of the location of quay walls or jetties and on the preparation of ship mooring and unmooring (Paulauskas, V., Paulauskas, D. 2009).

\section{Jetties in Ports Located at an Angle to the Direction of Current}

Jetties in ports play a very important role, because their construction requires less investments in comparison with classical quay walls and saves some space onshore (Wilhelm Ernst \& Sohn 2015; BS 6349-1:2000). Many ports use jetties in liquid and bulk terminals, because shore loading equipment or systems, in comparison with general cargo or other similar terminals, do not need much space and high payloads on the quay wall or jetty as well as onshore near the quay wall (Çakmak, Ersöz 2007; Wilhelm Ernst \& Sohn 2015; Paulauskas 2004).

At the same time, a number of ports have tidal or constant direction currents regularly acting on jetties constructed at an angle to the direction of currents. For example, port jetties in Klaipeda have been constructed at an angle of about $70^{\circ}$ to the direction of currents where current velocity in the positioned jetties sometimes reach up to 2-3 knots (Figs 4 and 5). Similar conditions can be observed in some other ports, particularly in those located in rivers (Figs 6 and 7).

In-depth studies and evaluation of ship mooring conditions in such places could very clearly explain the advantages and disadvantages of located jetties and assist in finding optimal decisions on planning and designing jetties under similar conditions as well as on increasing ship mooring and unmooring safety (Zalewski, Montewka 2007; Tomczak 2008; Paulauskas 1999).

In many cases, the ships mooring to quay walls or jetties under crosscurrent and such mooring operations request accurate preparedness and frequently powerful tug assistance.

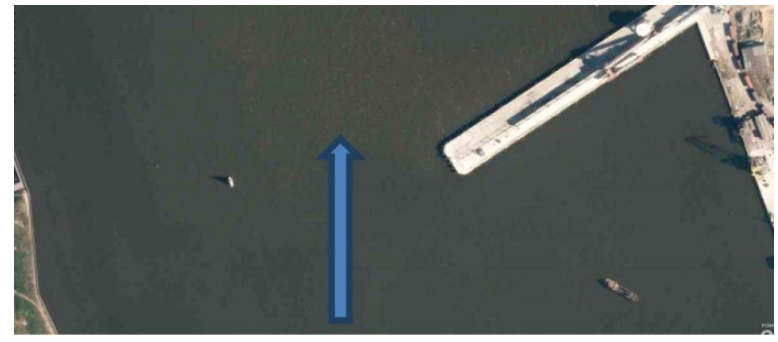

Fig. 4. Quay walls 66A and 67A located at an angle of $70-80^{\circ}$ to the current at the Port of Klaipeda

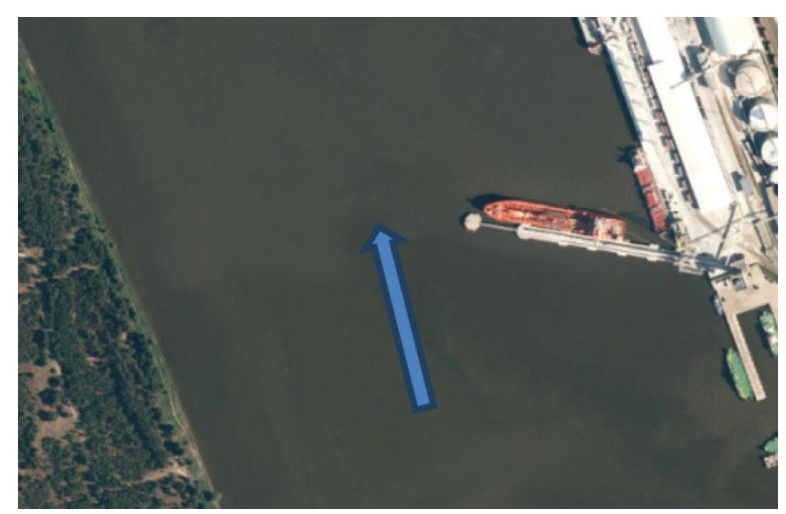

Fig. 5. Quay walls 71 and 72 located at an angle of $70^{\circ}$ to the current at the Port of Klaipeda

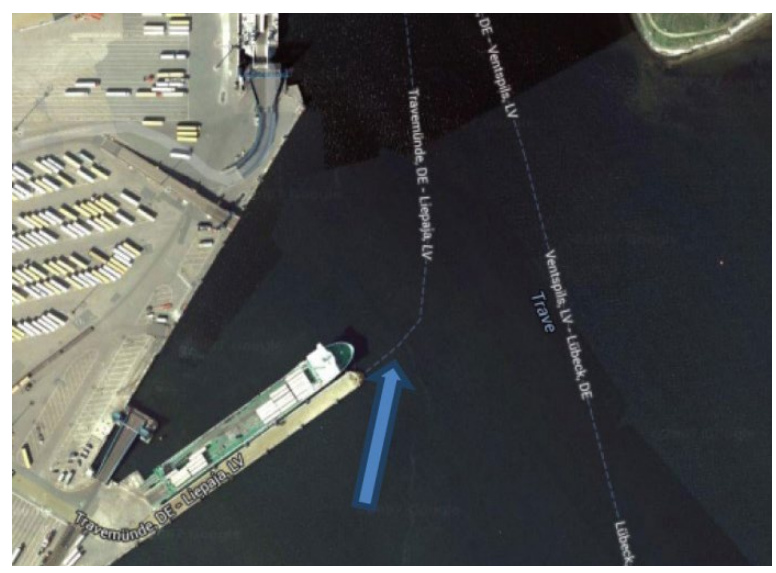

Fig. 6. A ro-ro jetty located at an angle of $50^{\circ}$ to the current at the Port of Travemünde

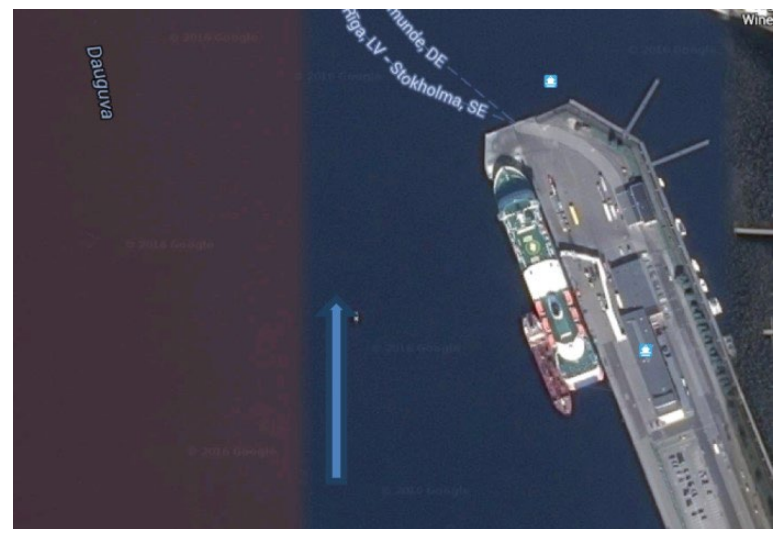

Fig. 7. A ro-ro terminal and current direction to the quay wall at the Port of Riga 
Calculation and evaluation models known in the ship theory and used today have limitations depending on the current acting on the distribution of the ship's hull. As a result, based on calculations or experimental data, the calibration of such models is very complex (Ok 2004; Wöckner-Kluwe 2013). Numerical models used for simulation request much initial data, and therefore very often it is really complicated to prepare them for many places in ports, or sometimes the preparation of the requested data on numerical models costs a lot and ports are not able to supply such models by corrected data.

\section{Theoretical Basis for the Model of Ship Mooring under Crosscurrent Conditions}

In many cases, ship mooring and unmooring occur parallel to quay walls and jetties whether the direction of the current is parallel or act at an angle in these places. Thus, a mathematical model for calculating forces and moments can be proposed in the following way (Paulauskas 2013):

$$
\begin{aligned}
& X_{i n}+X_{k}+X_{\beta}+X_{p}+X_{N}+X_{a}+X_{c}+ \\
& X_{b}+X_{s e k}+T_{x}+X_{V}+\ldots=0 ; \\
& Y_{i n}+Y_{k}+Y_{\beta}+Y_{p}+Y_{N}+Y_{a}+Y_{c}+ \\
& Y_{b}+Y_{s e k}+T_{y}+Y_{V}+\ldots=0 ; \\
& M_{i n}+M_{k}+M_{\beta}+M_{p}+M_{N}+M_{a}+M_{c}+ \\
& M_{c}+M_{b}+M_{\text {sek }}+M_{T}+M_{V}+\ldots=0,
\end{aligned}
$$

where: $X_{i n}, Y_{i n}, M_{i n}$ - inertia forces and the moment; $X_{k}$, $Y_{k}, M_{k}$ - forces and the moment created by the ship's hull; $X_{\beta}, Y_{\beta}, M_{\beta}$ - the ship's hull as the acting 'wing' related forces and the moment; $X_{p}, Y_{p}, M_{p}$ - forces and the moment created by the ship rudder or other steering equipment; $X_{M}, Y_{M}, M_{M}$ - forces and the moment created by thrusters; $X_{a}, Y_{a}, M_{a}$ - aerodynamic forces and the moment; $X_{c}, Y_{c}, M_{c}$ - forces and the moment created by the current; $X_{b}, Y_{b}, M_{b}$ - forces and the moment created by waves; $X_{\text {sek }}, Y_{\text {sek }}, M_{\text {sek }}$ - forces and the moment created by shallow water effect; $T_{x}, T_{y}, M_{T}$ - forces and the moment created by ship propellers; $X_{V}, Y_{V}, M_{V}-$ forces and the moment created by tugs.

Under ship mooring conditions, a request for a very low ship speed to the quay wall or jetty must be submitted, and the ship should mainly move at a small drift angle, which means that the drift angle of the ship reaches not more than $5^{\circ}$; in this case $-X_{k}, Y_{k}$ and $M_{k}$ are close to $0 ; X_{p}$, in case of a low speed - can be considered negligible.

The existing calculation models do not include forces and moments created by the 'wing effect' as well as current distribution along the ship's hull and current parameters changing clause to the jetty in case a mooring ship partly blocks current flow and decreases the cross square of the channel (Rawson, Tupper 2001).

At the same time, in many cases, the longitudinal ship's speed, when a vessel is close to the quay wall or jetty, is very low and has a minimum influence on the construction elements of quay walls or jetties (PIANC 1995).
Ship movement towards the quay wall or jetty is adjusted by ship equipment (thrusters, ruder and propeller), and, in many cases, by tugs. Simultaneously, the crosscurrent to the quay wall or jetty has a very big influence, particularly during mooring/unmooring of a large ship having a deep draft. The influence (force) of the crosscurrent can be calculated as follows (Paulauskas 2013):

$$
Y_{c}=C_{c} \cdot \frac{\rho}{2} \cdot F_{d} \cdot\left(v_{c} \cdot \sin q_{c}\right)^{2},
$$

where: $C_{c}-$ the hydrodynamic coefficient of the ship's hull located perpendicular to the current can be taken as $1.2-1.5$ for practical calculations; $\rho$ - water density; $v_{c}$ - current velocity in the mooring place of the ship; $q_{c}$ - the angle of the course of the current to the quay wall; $F_{d}$ - the square of the underwater projection of the ship for the median plane can be calculated as follows:

$$
F_{d}=L \cdot T \cdot \gamma,
$$

where: $L$ - a ship's length between perpendiculars; $T$ the average ship's draft; $\gamma$ - the coefficient of the underwater square of the ship could be taken as $0.95-1.0$ for sea going ships.

As for the ports having narrow channels, quay walls or jetties located close to the navigational channel, moored ships partly block current flow and, in reality, decrease the cross square of the channel, which, as a result, increases current velocity (Fig. 8).

The average current velocity $v_{c}^{\prime}$ increasing near a free part of the navigational channel could be calculated based on the following dependency:

$$
v_{c} \cdot S_{c h}=v_{c}^{\prime} \cdot S_{c h}^{\prime}
$$

where: $v_{c}^{\prime}$ - average current velocity; $S_{c h}$ - the initial square of the cross channel; $S_{c h}^{\prime}$ - the cross square of the channel in case the channel is partly blocked by the ship's hull.

From the last dependency, the average current velocity could be calculated as follows:

$$
v_{c}^{\prime}=\frac{S_{c h}}{S_{c h}^{\prime}} \cdot v_{c} .
$$

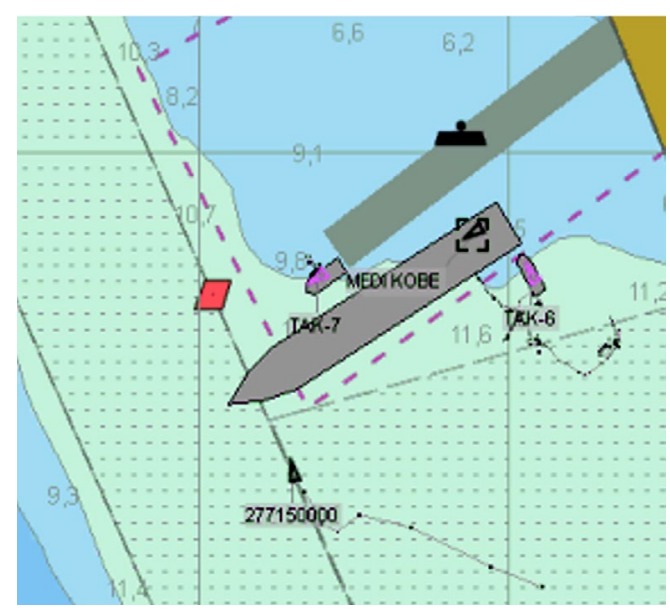

Fig. 8. A mooring ship partly blocks current flow and decreases the cross square of the channel 
At the same time, the distribution of current velocity is not linear along the ship's hull and the crosssection of the channel, which means that the influence of the current on the ship is different in the ship's bow and astern. The current has more influence on the part of the ship located close to the central line of the channels; simultaneously, depths decrease towards the central line of the channel in some ports.

In the above mentioned situation, the current harder presses the ship in the part closer to the central line of the channel, which, in general, could be taken as the average current velocity acting on the ship's hull, as shown in Fig. 9.

Current velocity in the ship's bow area $v_{c \text { (bow })}$ could be calculated as follows:

$$
v_{c(\text { bow })}=a \cdot v_{c}^{\prime} \text {. }
$$

Current velocity in the ship's astern area $v_{c(\text { ast }}$ could be calculated as follows:

$$
v_{c(\text { ast })}=b \cdot v_{c}^{\prime},
$$

where: $a, b$ - coefficients that could be expressed by the cross-sections of the channel, which is:

$$
\begin{aligned}
& a=\frac{S_{c h}}{S_{c h}^{\prime}} ; \\
& b=\frac{S_{c h}^{\prime}}{S_{c h}} .
\end{aligned}
$$

For ship mooring prospects, the distribution of the forces created by the current is an important point and can be calculated as:

$$
\begin{aligned}
& F_{\text {bow }}=C_{y} \cdot \frac{\rho}{2} \cdot F_{d} \cdot\left(v_{c(\text { bow })}\right)^{2} ; \\
& F_{\text {ast }}=C_{y} \cdot \frac{\rho}{2} \cdot F_{d} \cdot\left(v_{c(\text { ast })}\right)^{2} .
\end{aligned}
$$

In case of the ship moving to the quay wall or jetty, a request for tug bollard pull could be at least not less than the forces created by the current on the ship's hull and could be calculated as:

$$
\begin{aligned}
& Y_{V(\text { bow })}=F_{b o w} ; \\
& Y_{V(\text { ast })}=F_{\text {ast }} .
\end{aligned}
$$

The ship's turning moment depends on the condition of ship movement, i.e. on the location of the pivot point as shown in Fig. 10 (ship in the stop position), Fig. 11 (ship moves ahead) and Fig. 12 (ship moves astern).

In the case of the stop position (Fig. 10), the pivot point of the ship is located close to the middle part of the ship, and turning moments to keep the ship in one direction could be expressed as:

$$
\begin{aligned}
& M_{\text {bow }}=F_{b o w} \cdot \frac{L}{2} ; \\
& M_{\text {ast }}=F_{\text {ast }} \cdot \frac{L}{2} .
\end{aligned}
$$

In the case of the ship moving ahead (Fig. 11), the position of the pivot point will be close to the bow and turning moments keeping the ship in one direction could be expressed as:

$$
\begin{aligned}
& M_{\text {bow }}=0.3 \cdot L \cdot F_{b o w} ; \\
& M_{\text {ast }}=0.7 \cdot L \cdot F_{\text {ast }} .
\end{aligned}
$$

In the case of the ship moving astern (Fig. 12), the position of the pivot point will be close to the ship's astern and turning moments keeping the ship in one direction could be expressed as:

$$
\begin{aligned}
& M_{\text {bow }}=0.7 \cdot L \cdot F_{b o w} ; \\
& M_{\text {ast }}=0.3 \cdot L \cdot F_{\text {ast }} .
\end{aligned}
$$

To keep the balance of turning moments when the ship moves parallel to the quay wall means that:

$$
M_{\text {bow }}=M_{\text {ast }} \text {. }
$$

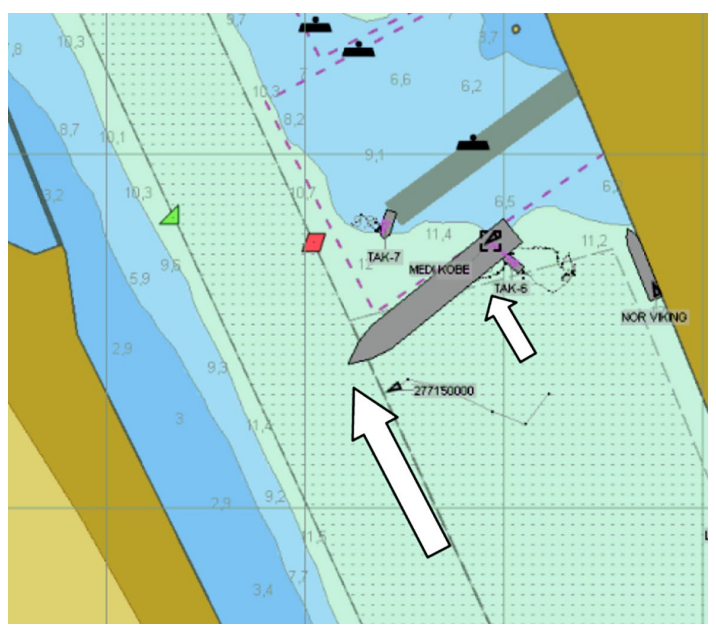

Fig. 9. The current acting on different parts of the ship

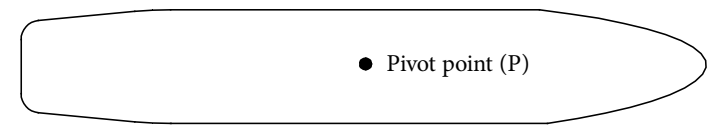

Fig. 10. The location of the pivot point of the ship in the stop position

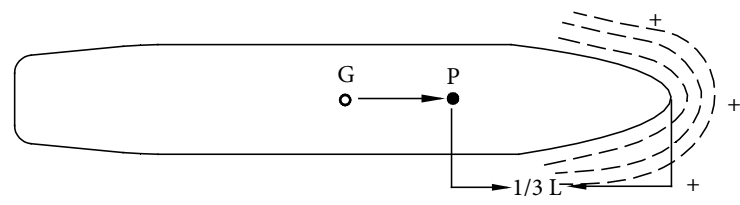

Fig. 11. The location of the pivot point when the ship moves ahead

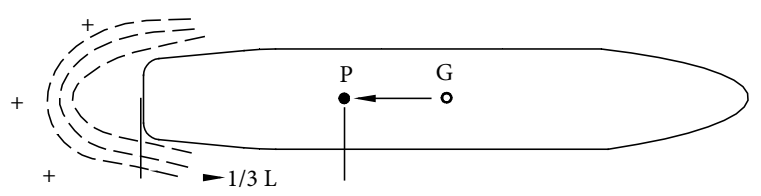

Fig. 12. The location of the pivot point when the ship moves astern 
Based on the balance of turning moments, the required tug bollard pull in the ship's bow and astern can be calculated so that the ship will move or stop parallel to the quay wall or jetty:

$$
Y_{V(\text { bow })}=\frac{S_{c h}^{2}}{S_{c h}^{\prime 2}} \cdot Y_{V(\text { ast })} \text {. }
$$

In the case of the ship moving ahead and keeping the ship parallel to the quay wall or jetty, difference in tug bollard pull could be expressed as:

$$
Y_{V(\text { bow })}=2.3 \cdot \frac{S_{c h}^{2}}{S_{c h}^{\prime 2}} \cdot Y_{V(\text { ast })} \text {. }
$$

In the case of the ship moving astern and keeping the ship parallel to the quay wall or jetty, difference in tug bollard pull could be expressed as:

$$
Y_{V(\text { bow })}=0.4 \cdot \frac{S_{c h}^{2}}{S_{c h}^{\prime 2}} \cdot Y_{V(\text { ast })} \text {. }
$$

Based on the presented methodology, it is possible to calculate a request for tug bollard pull. Tug location depends on the ship's length, the configuration of the navigational channel and distances between the middle line of the navigational channel and quay walls or jetties, current velocity and direction as well as other external factors acting on mooring the ship to the quay wall or jetty under crosscurrent conditions.

\section{Practical Testing of Tug Bollard Pull during Ship Mooring under Crosscurrent Conditions}

For practical testing, a case study on real ship mooring to the jetty (quay wall 67A) located at an angle of $70^{\circ}$ (Fig. 13) to the current in the port of Klaipeda was used. As a testing example, POST PANAMAX bulk ship MEDI KOBE of $225 \mathrm{~m}$ in length, $32 \mathrm{~m}$ in width and a full draft of $14.0 \mathrm{~m}$ (during the case study, draft was 10.5 $\mathrm{m})$ was taken. Under the cross-section of the channel $S_{c h}=6500 \mathrm{~m}^{2}$ and a decrease in the cross-section of the channel $S_{c h}^{\prime}=4420 \mathrm{~m}^{2}$, current velocity was 0.8 knots at an angle of $80^{\circ}$ of the current to the jetty. Three tugs with $500 \mathrm{kN}$ bollard pull were used - 2 tugs in the ship's bow and 1 tug in the ship's astern. 2 of the above mentioned tugs used tug ropes ( 1 in the bow and 1 in the astern) and 1 tug worked in the bow applying to the push/pull method (Paulauskas, V., Paulauskas, D. 2011).

On the basis of the methodology presented in Section 2 and classical methods of the ship theory (Rawson, Tupper 2001), the necessary tug bollard pull required for keeping the ship against the current and wind can be calculated (the wind was perpendicular to the jetty, under a velocity of $10 \mathrm{~m} / \mathrm{s}$, the underwater area of the vessel affected by the wind was about $3800 \mathrm{~m}^{2}$ ).

All calculation results are presented in Figs 14-16.

The results received applying classical methods of the ship theory of the tested case (bulk ship MEDI KOBE) have shown that, taking into account the above described situation when $90 \%$ of the used tugs bollard pull is created by 3 tugs having $500 \mathrm{kN}$ tug bollard pull each, the possibility of ship mooring, in case of the current velocity up to $0.87 \mathrm{~m} / \mathrm{s}$.

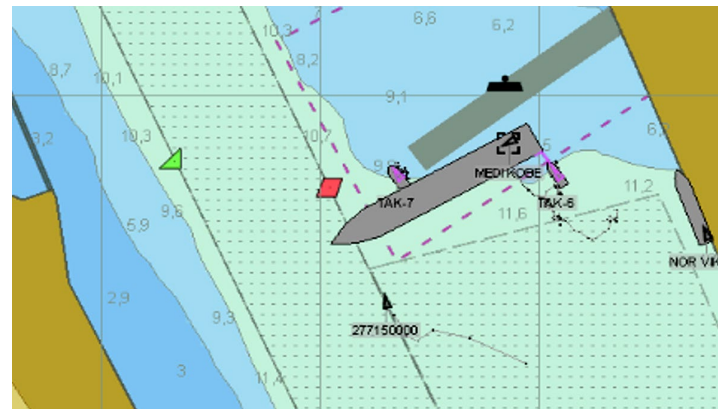

Fig. 13. Bulk ship MEDI KOBE mooring in the crosscurrent with 2 tugs in the bow and 1 tug in the astern (every tug bollard pull is equal to $500 \mathrm{kN}$ )

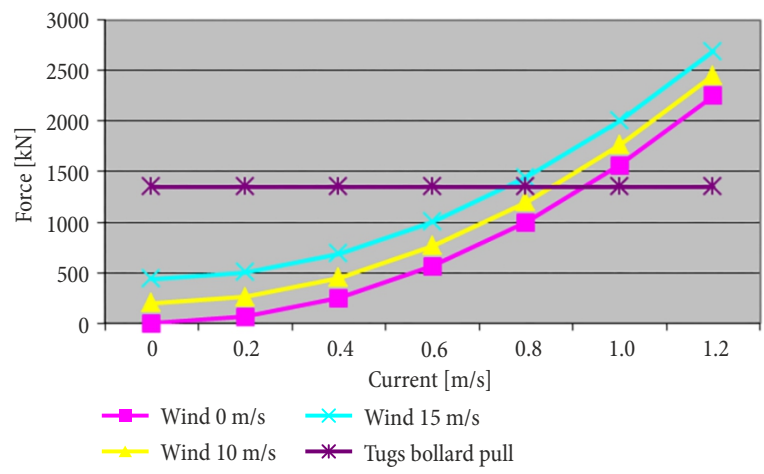

Fig. 14. Forces created by the wind perpendicular to the ship, the current acting at an angle of $70^{\circ}$ to the ship's hull and

3 tug bollard pulls (each tug has the capacity of $500 \mathrm{kN}$ bollard pull) received by the classical ship theory

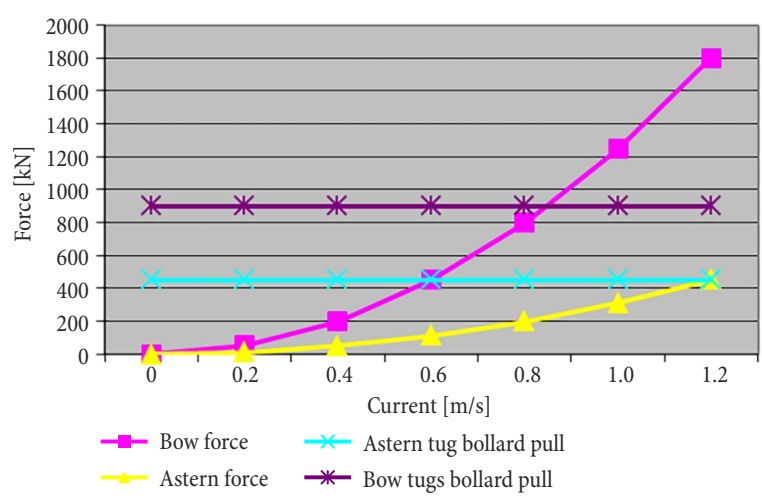

Fig. 15. Forces created by the current acting at an angle of $70^{\circ}$ to the ship's hull and 2 tugs working on the ship's bow and 1 tug working on the ship's astern (each tug has the capacity of $500 \mathrm{kN}$ bollard pull) required tugs bollard pull

received by the method presented in the article

According to the methodology presented in Section 2, the received total required tugs bollard pull in the ship's bow made about $700 \mathrm{kN}$ and that in the ship's astern required about $180 \mathrm{kN}$.

The results received using the method presented in this article in case if no wind acting and used separately bow and astern tugs bollard pull up to $90 \%$ of the 3 tugs with bollard pull $500 \mathrm{kN}$ each, similar ship (bulk ship MEDI KOBE) shown that ship's mooring operations could be safety made in case of current velocity up to $0.82 \mathrm{~m} / \mathrm{s}$ (limitation has bow tugs). 


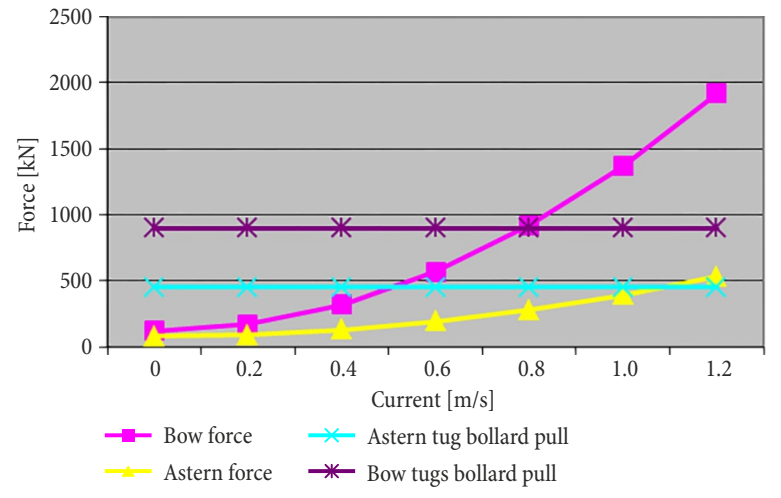

Fig. 16. Forces created by the wind of $10 \mathrm{~m} / \mathrm{s}$ perpendicular to the ship and the current acting at an angle of $70^{\circ}$ to the ship's hull and 2 tugs work on ship bow and 1 tug work on ship astern (each tug has the capacity of $500 \mathrm{kN}$ bollard pull) bollard pull, received by methods presented in the article

Received results by methodology presented in this Article in case of wind $10 \mathrm{~m} / \mathrm{s}$ acting perpendicular to ship hull and current acting with angle $70^{\circ}$ to ship's hull (in this situation could be use $90 \%$ of the 3 tugs with tug bollard pull $500 \mathrm{kN}$ each) show that for the ship, presented in case study, safe mooring maximum current velocity could be up to $0.78 \mathrm{~m} / \mathrm{s}$ (limitation has bow tugs).

During the mooring operation of bulk ship MEDI KOBE, tug bollard pull was fixed every $30 \mathrm{~s}$ in the ship's position parallel to the jetty. The forces of the tugs that work using tug ropes were fixed by tug rope tension registrar, having the accuracy of up to $5 \mathrm{kN}$, and tug, which work by pull/push method forces were calculate on basis engine manoeuvre registrar results, which fixed power with accuracy up to $5 \mathrm{~kW}$. The tension of the tug rope and the power of the main engine were recorded on tug computer every second. The obtained results presented in Fig. 17 show that a request for tug bollard pull to keep the ship parallel to the jetty against the current and wind correlates with calculation results.

The analysis of the results received employing a different calculation technique (classical method presented in this article) has shown the main advantage of the presented method showing it is possible to beforehand calculate separate forces on the ship's bow and astern and to order optimal tugs before mooring operations, which is very important in case the port has a limited number and powerful tugs. The received experimental results on real ship during mooring operations have shown a good correlation between the results received by the method presented in this article and experimental results received under real conditions. The found differences did not reach more than $10 \%$.

Finally, bulk ship MEDI KOBE was moored to the jetty as shown in Fig. 18. About $25 \mathrm{~m}$ of the ship's bow was outside the jetty.

The calculations and experimental results received under real conditions show that the methodology presented in the article could be used for the quay wall or planning jetty and ship mooring under crosscurrent

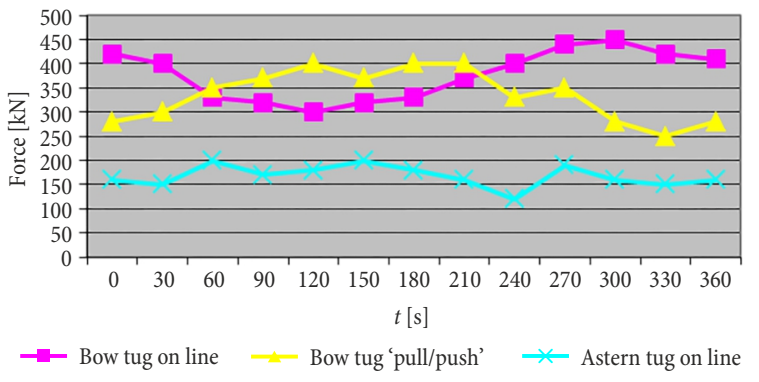

Fig. 17. Tug bollard pull during the ship mooring operation

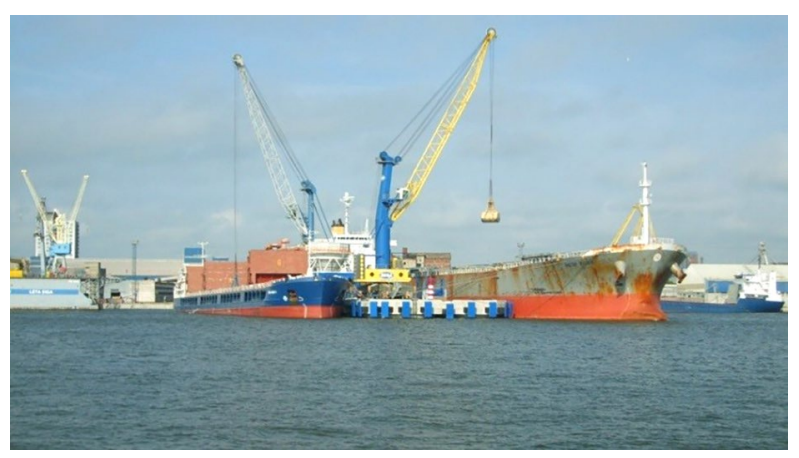

Fig.18. Bulk ship MEDI KOBE moored to the jetty (quay wall 67A) at the port of Klaipeda

conditions acting to the quay wall or jetty. The selection of an optimal number of tugs and their positioning depend on the created forces. As example, presented in study case, was enough just one tug work in ships astern with tug bollard pull $300 \mathrm{kN}$.

\section{Conclusions}

Quay walls and jetties found in crosscurrent conditions are frequently met in many ports located in rivers and other places to save water space in some of the ports. The evaluation of ship mooring safety parameters in advance is very important.

The methodology presented in the article could be successfully used under complex ship mooring conditions for calculating an optimal request for tug bollard pull and tugs located along ship's hull in case of the crosscurrent acting on quay walls or jetties.

The forces and moments presented in the article and acting on ships under crosscurrent conditions were checked in real ships under real conditions and showed a good correlation with calculation results, although differences did not reach more than $10 \%$.

A comparison of ship mooring under crosscurrent conditions considering classical calculation methods for the ship theory and the method presented in the article has shown that differences can reach up to $12-15 \%$.

The analysis of the results received employing different calculation methods (classical and the one presented in this article) has demonstrated the main advantage of the developed technique and has indicated it is possible to beforehand calculate forces on the ship's bow and astern, which can be a basis for ordering and locating optimal tugs before mooring operations. 
In-depth investigations and knowledge about forces and moments, under crosscurrents acting on quay walls or jetties, can increase navigational safety for mooring ships and help with avoiding possible losses for vessels and ports in case of accidents or incidents in such unfavourable circumstances.

\section{References}

BS 6349-1:2000. Maritime Structures. Code of Practice for General Criteria.

Çakmak, T., Ersöz, F. 2007. Methodology recommendation for one-criterion transportation problems: Çakmak method, Transport 22(3): 221-224.

Gucma, L.; Montewka, J. 2005. Landborne laser rangefinder measurements for navigation safety assessment, European Journal of Navigation 3(4): 1-6.

Lee, C.-K.; Lee, S.-G. 2008. Investigation of ship maneuvering with hydrodynamic effects between ship and bank, Journal of Mechanical Science and Technology 22(6): 1230-1236. https://doi.org/10.1007/s12206-008-0309-9

Ok, J.-P. 2004. Numerical Investigation of Scale Effects of Schneekluth's Duct. Hamburg University of Technology. $92 \mathrm{p}$.

Paulauskas, V. 2013. Ships Entering the Port: monograph. Riga: N.I.M.S. $240 \mathrm{p}$.

Paulauskas, V.; Paulauskas, D. 2011. Research on work methods for tugs in ports, Transport 26(3): 310-314. https://doi.org/10.3846/16484142.2011.623825

Paulauskas, V.; Paulauskas, D. 2009. Laivo valdymas uoste. Klaipeda: Klaipedos universiteto leidykla. 256 p. (in Lithuanian).

Paulauskas, V. 2004. Uostu terminalu planavimas. Klaipeda: Klaipedos universiteto leidykla. 382 p. (in Lithuanian).

Paulauskas, V. 1999. Laivo valdymas ypatingomis salygomis. Klaipeda: Klaipedos universiteto leidykla. 164 p. (in Lithuanian).

PIANC. 2002. Guidelines for the Design of Fender Systems. The World Association for Waterborne Transport Infrastructure (PIANC).

PIANC. 1995. Criteria for Movements of Moored Vessels in Harbours. The World Association for Waterborne Transport Infrastructure (PIANC).

PIANC. 1984. Report of the International Commission for Improving the Design of Fender Systems. The World Association for Waterborne Transport Infrastructure (PIANC).

Rawson, K. J.; Tupper, E. C. 2001. Basic Ship Theory. 5th edition. Butterworth-Heinemann. $784 \mathrm{p}$.

Skjetne, R. 2003. Ship maneuvering: the past, the present and the future, Sea Technology 44(3): 33-37.

Tomczak, A. 2008. Safety evaluation of ship's maneuvers carried out on the basis of integrated navigation systems (INS) indications, Journal of Konbin 4(1): 247-266. http://dx.doi.org/10.2478/v10040-008-0021-y

Wilhelm Ernst \& Sohn. 2015. Recommendations of the Committee for Waterfront Structures Harbours and Waterways $E A U$ 2012. 9th edition. Wiley. 676 p. https://doi.org/10.1002/9783433605172

Wöckner-Kluwe, K. 2013. Evaluation of the Unsteady Propeller Performance behind Ships in Waves: Dissertation. Hamburg University of Technology. $145 \mathrm{p}$. https://doi.org/10.15480/882.1139
Zalewski, P; Montewka, J. 2007. Navigation safety assessment in an entrance channel, based on real experiments, in Proceedings of the 12th International Congress of the International Maritime Association of the Mediterranean (IMAM 2007), 2-6 September 2007, Varna, Bulgaria, 1113-1120. 